\title{
The Usage of CIDOS and Social Network Sites in Teaching and Learning Processes at Malaysian Polytechnics
}

Sharifah Nadiyah Razali ${ }^{1}$, Faaizah Shahbodin ${ }^{2}$

Faculty of Information and Communication Technology

Malaysia Technical University, Malacca

shnadiyah@yahoo.com

Faculty of Information and Communication Technology

Malaysia Technical University, Malacca

\section{ABSTRACT}

faaizah@utem.edu.my

In $21^{\text {st }}$ century learning, students use educational technologies to apply knowledge to new situations, analyse information, collaborate, solve problems, and make decisions. Utilising emerging technologies, to provide expanded learning opportunities, is critical to the success of future generations. In this paper, the author will share the findings on the usage of CIDOS and Social Network Sites in teaching and learning processes at Malaysian Polytechnics. Two sets of questionnaires were distributed to a group of 84 diploma students and 41 lecturers from Politeknik Ibrahim Sultan, Politeknik Merlimau, Politeknik Tuanku Syed Sirajuddin, Politeknik Kota Kinabalu, and Politeknik Sultan Idris Shah. The results of the study show the existence of communication and interaction difficulties in existing Learning Management Systems (LMS). As a recommendation for future research, it is suggested to integrate current LMS with Facebook to support Online Collaborative Learning (OCL).

\section{Indexing terms/Keywords}

Learning Management System (LMS), Social Network Sites (SNSs), Online Collaborative Learning (OCL)

\section{Academic Discipline And Sub-Disciplines}

Education

\section{SUBJECT CLASSIFICATION}

Nutrition Subject

TYPE (METHOD/APPROACH)

Survey

\section{Council for Innovative Research}

Peer Review Research Publishing System

Journal: INTERNATION JOURNAL OF COMPUTERS AND TECHNOLOGY

Vol. 13, No. 4

editorijctonline@gmail.com

www.cirworld.org/journals 


\section{INTRODUCTION}

The emergence of open source Learning Management System (LMS) platforms, such as Moodle, has drastically expanded the scope of e-learning; thus leading to a diversity of situations, adjusted to specific educational demands. In Polytechnics, an open source LMS called CIDOS is currently being used. Through e-learning, learning can take place anywhere and at any time through the communication tools that it has. This feature provides a channel of communication among students and lecturers that is not bounded by class time and physical presence. In $21^{\text {st }}$ century learning, students use educational technologies to apply knowledge to new situations, analyse information, collaborate, solve problems, and make decisions. Utilizing emerging technologies to provide expanded learning opportunities is critical to the success of future generations. Historically, Learning Management Systems (LMS) offer a relatively static one-way learning experience; from content to learners. E-learning systems appear to have reached a plateau, and they are greatly in need of the next stage of development i.e., the integration of social and collaborative tools to enhance the learning process. Few educators utilize the use of Social Network Sites (SNSs), such as Facebook, in their education. The 'bundling' together of LMS with SNSs not only transforms their lecturer/student offering dynamically, it also gives the learner a voice to contribute, share knowledge, and become part of a collaborative learning program. Along with SNSs, the web has become an interactive platform for contribution and collaboration.

The National Higher Education Strategic Plan (PSPTN), which was formed based on Core 2 in the $9^{\text {th }}$ Malaysia Plan (MP - 9) clearly states that in order to achieve Vision 2020, the country must raise its capacity for knowledge and innovation and nurture first class mentality. Since 2011, there have been four PSPTN implementation phases, the second of which, is to strengthen and empower the higher education sector during the $10^{\text {th }}$ Malaysia Plan (MP - 10), which will end in 2015. PSPTN contains seven cores, and through the second PSPTN core, the Ministry of Higher Education (MoHe) hopes to improve the quality of teaching and learning, in order to produce competent graduates. Twenty three (23) Critical Agenda Projects (CAP) have been created to achieve PSPTN, of which one is e-learning. The development of information and communication technologies that enable rapid learning and teaching is made through the use of a network that connects students and lecturers, students and students, and students with global web material online. The use of information and communication technology to facilitate the process of teaching and learning; or more specifically, e-learning; makes students more active and responsible for their learning. The concept of such a devoted student, learning through elearning technology, is expected to produce graduates that are more responsible, independent, and self-reliant, and can compete in an international arena.

Most educational institutions have currently adopted a Learning Management System (LMS), either from an open source, such as Moodle and Sakai, or from a commercial source, such as Blackboard, to centralize contents, learning, and assessment activities in one learning environment (Carlos et al., 2013; Coates, H., James, R. \& Baldwin, 2005). An LMS provides students and lecturers with a set of tools for improving and managing the learning process (García-Peñalvo, J., Conde, Alier, \& Casany, 2011). They also provide a platform on the web, and many pedagogical activities can perform on them. Students can use LMS features, such as discussion boards or forums, to facilitate their communications and collaborative work in this learning environment. However, the communication features of LMSs are poorly utilized in most institutions, because they are being used primarily as course content features for lecture notes and presentation slides. Marijana, Aleksandra, and Aleksandar (2011) report that the frequency of LMS use by educational institutions is very low and has become unpopular among lecturers. In research conducted by Afendi, Mohamed Amin, and Abdul Halim (2011) into Malaysian Higher Education Institutions (HEIs), the authors reported that the reason why HEls still use LMS in teaching is because of their course content facilities. Among the samples included in the study were Ungku Omar Polytechnic, Johor Bahru Polytechnic, and Shah Alam Polytechnic. However, this result shows that the communication feature was the least used of all features, and lecturers preferred to employ Social Network Sites (SNSs) to facilitate their communication. This exposes LMS weaknesses in the field of communication and collaboration among users. Similarly, Hern'ndez, Amado-Salvatierra, Guetl, \& Smadi, (2012) used other replacement applications as a built-in discussion forum in an LMS. A very common theme in Moodle forums is that of problems with email notifications, for things like submitted assignments, forum posts, graded assignments, etc.

Learning through Social Network Sites (SNSs) is currently a trending topic; especially since many studies have reported that students spend more time online on SNSs (Hern'ndez et al., 2012). Studies have shown that online social networking tools enable interaction, collaboration, resource sharing, active participation, and critical thinking in educational activities (Ajjan, H., Hartshorne, 2008; Chen, 2011; Mason, 2006; Selwyn, 2007). However, Li, Dong, Untch, Chasteen, \& Reale, (2011) believe that other social connections within SNSs may cause distraction to students; especially freshmen students. Therefore, the researcher agrees with Embi, (2011); D. Marijana, Aleksandar, Zorica, Dušan, \& Krčo, (2012) to upgrade existing LMSs with a social function. Even though many educational researchers have looked into the potential of adapting SNSs in their teaching and learning processes, (D.-Z. Marijana et al., 2011; Al-Zoube, 2009; McCarthy, 2009), several studies have been conducted on integrating conventional LMSs, such as Moodle, with SNSs. This has left a gap in the body of knowledge on how LMSs can be integrated with an SNS platform, to effectively facilitate learning; especially in an online learning environment. According to Suthathip and Songrit (2012), educational technology researchers, who are interested in studying and developing new student-centred learning, should pay attention to students' demands. This paper shares the preliminary findings on the perceptions of students and lecturers on the use of CIDOS and SNSs in learning and teaching processes, and identifies SNSs, based on student and lecturer preferences. Discussion and future research is provided based on the findings of this study. 


\section{METHODOLOGY}

Two survey instruments were used in this study, namely student and lecturer surveys. The lecturer survey was a 23 -item questionnaire and the student survey was a 19-item questionnaire. Both questionnaires consisted of two parts; CIDOS and SNSs. Both instruments were adapted and modified from Embi (2011). In this study, the Cronbach's Alpha was 0.863 for the student survey instrument and 0.832 for the lecturer survey instrument. Ghaffar (1999) indicates that a questionnaire has a high reliability if the Cronbach's Alpha is above 0.80 . It can therefore be concluded that the internal consistency of the data was achieved.

The questionnaires were distributed to $84(\mathrm{~N}=84)$ Diploma in Hotel Catering and Tourism Management students, and 41 $(\mathrm{N}=41)$ lecturers of the Hospitality and Tourism Department from Politeknik lbrahim Sultan, Politeknik Merlimau, Politeknik Tuanku Syed Sirajuddin, Politeknik Kota Kinabalu, and Politeknik Sultan Idris Shah.

\section{FINDING}

This section presents the findings, based on the focus of this study, which is to discover the usage of CIDOS and SNSs in teaching and learning processes at Malaysian Polytechnics. Therefore, only the focus relevant items are presented in this section.

In terms of CIDOS usage trends, Table 1 shows that the two main CIDOS features most frequently used by students were Assessment $(82.14 \%)$ and Course Management $(73.81 \%)$, while the least used features in CIDOS by students were Productivity (20.24\%) and Communication (16.67\%). Next, as shown, the two main CIDOS features most frequently used by lecturers were Assessment (95.12\%) and Course Management (80.49\%). However, the least used features by lecturers were Communication (48.78\%) and Productivity (68.29\%).

Table 1: Percentage of CIDOS access by students and lecturers

\begin{tabular}{ccccc}
\hline CIDOS features & Students & $\%$ & Lecturers & $\%$ \\
\hline Communication (e.g. Forum, Chat) & 14 & 16.67 & 20 & 48.78 \\
Productivity (e.g. Calendar, Schedule) & 17 & 20.24 & 28 & 68.29 \\
Course Management (e.g. Content Sharing, Student Enrolment) & 62 & 73.81 & 33 & 80.49 \\
Assessment (e.g. Grade books, Tracking) & 69 & 82.14 & 39 & 95.12
\end{tabular}

As shown in Table 2, Social networking, such as Facebook, MySpace, and Twitter, was the most commonly used alternative application by lecturers to complement the LMS provided by their institutions (39.02\%), followed by Content Sharing (21.95\%), Collaboration Tools (19.51\%), Photo/Video Sharing (12.20\%), Blogs (7.32\%), and Communication Tools (4.885).

Table 2: Alternative applications to complement LMS

\begin{tabular}{llc}
\hline \multicolumn{1}{c}{ Alternative applications to compliment CIDOS } & Freq. & $\%$ \\
\hline Social Networking (e.g. Facebook, MySpace, Twitter) & 16 & 39.02 \\
Content Sharing (e.g. Slide share) & 9 & 21.95 \\
Collaboration Tools (e.g. Wikis, Google Docs) & 8 & 19.51 \\
Photo/Video Sharing (e.g. Flickr, YouTube) & 5 & 12.20 \\
Blogs (e.g. WordPress, BlogSpot) & 3 & 7.32 \\
Communication Tools (e.g. Yahoo Messenger, Skype) & 2 & 4.88 \\
\hline TOTAL & 41 & 100 \\
\hline
\end{tabular}


Table 3 shows the percentage of SNSs based on students' and lecturers' preferences. $95.24 \%$ of students and $95.12 \%$ of lecturers preferred Facebook as their favourite SNS. Table 4 shows both lecturers and students more frequent to access their preferred SNSs per day compare to access Cidos.

Table 3: Social Network Sites based on students' and lecturers' preferences

\begin{tabular}{lcccc} 
SNSs & Students & $\%$ & Lecturers & $\%$ \\
\hline Linkedln & 0 & 0.00 & 0 & 0.00 \\
Pinterest & 0 & 0.00 & 0 & 0.00 \\
Other & 1 & 1.19 & 1 & 2.44 \\
MySpace & 7 & 8.33 & 2 & 4.88 \\
Twitter & 41 & 48.81 & 6 & 14.63 \\
Facebook & 80 & 95.24 & 39 & 95.12 \\
\hline
\end{tabular}

Table 4: Frequently access per day

\begin{tabular}{lcccc}
\hline & \multicolumn{2}{c}{ Cidos } & \multicolumn{2}{c}{ SNSs } \\
& Frequency & $\%$ & Frequency & $\%$ \\
\hline Students & 5 & 6 & 82 & 97.5 \\
Lecturers & 3 & 7.3 & 40 & 97.5 \\
\hline
\end{tabular}

\section{DISCUSSION AND CONCLUSION}

Most educational institutions have implemented LMS to centralise contents, learning, and assessment activities, in one single learning environment. Students and lecturers use forums and discussion boards to facilitate their communication and collaboration work. However, from the results, it was found that lecturers preferred to employ Social Network Sites to facilitate their communication rather than using LMS. This shows that there were weaknesses in LMS, in the field of communications and collaboration among users. These results are similar to those achieved by Hern'ndez, AmadoSalvatierra, Guetl, \& Smadi (2012). The authors used other replacement applications for built-in discussion forums within LMS. This result differs from that reported by Li, Dong, \& Untch (2011), who believed that SNSs may cause distraction to students; especially newly enrolled students. Therefore, the author of this present study agrees with Despotović-zrakić, Marković, Bogdanović, Barać, \& Srdjan (2012), and Embi (2011), that the existing LMSs should be upgraded with a social network function.

Recent studies have reported on how Facebook can be used to enhance both the learning process (Ractham \& Firpo, 2011) and collaboration activities (Cerdà \& Planas, 2011; Hern'ndez et al., 2012). In contrast to the findings by Ishan Sudeera \& Tham (2011), Facebook simply cannot be successful in meeting the needs of students; it can only be used as a supplement, due to the incapability and limitations of LMS, such as in networking and communications. The findings from the survey of this present study indicate that $95 \%$ of students and $98 \%$ of lecturers have their own SNS accounts, and $95.24 \%$ of students and $95.12 \%$ of lecturers were Facebook subscribers. Suthathip and Songrit (2012) found that students preferred to use tools that they were familiar with. Therefore, during the next stage of this present research, the author will incorporate Learning Management System (LMS) with Facebook, to enable students and lecturers communicate on Moodle through Facebook. This will be used as an instrument to support Online Collaborative Learning (OCL).

\section{ACKNOWLEDGEMENT}

The author would like to thank people who have been supportive throughout this study. First and foremost, Associate Professor Dr. Faaizah binti Shahbodin, Dr. Norasiken binti Bakar, and Associate Professor Dr. Hanipah binti Hussin for their advice, support, encouragement, and guidance. The author would also like to thank the management, lecturers, and students of the polytechnics for their involvement, cooperation, and support in this study. Last but not least, the author would like to express an infinite love to her beloved husband, family, and colleagues for giving much support and encouragement. This research was done by a Ph.D candidate from UTeM. 


\section{REFERENCES}

[1] Afendi, H., Mohamed Amin, E., \& Abdul Halim, S. (2011). Learning Management Systems in Malaysian Higher Education Institutions (pp. 29-50).

[2] Ajjan, H., Hartshorne, R. (2008). Investigating faculty decisions to adopt Web 2.0 technologies: theory and empirical tests. (pp. 71-80).

[3] Al-Zoube, M. (2009). E-Learning on the Cloud. International Arab Journal of E-Technology, 1(2), 58-64.

[4] Carlos, A.-H., Miguel L., B.-L., Eduardo, G.-S., Juan I., A.-P., Guillermo, E.-G., \& Adolfo, R.-C. (2013). Enhancing Learning Environments by Integrating External Applications. Bulletin of the IEEE Technical Committee on Learning Technology, 15(1), 21-24.

[5] Cerdà, F. L., \& Planas, N. C. (2011). Facebook's Potential for Collaborative e-Learning. RUSC. Universities and Knowledge Society Journal, 8(2), 197-210.

[6] Chen, Y. (2011). Learning styles and adopting Facebook technology. In Technology Management in the Energy Smart World (PICMET) (pp. 1-9).

[7] Coates, H., James, R. and Baldwin, G. (2005). A critical examination of the effects of learning management systems on university teaching and learning,. Tertiary Education and Management, 11(1):19-36, 2005., 11(1), $19-36$.

[8] Embi, M. A. (2011). e-learning in Malaysian Higher Education: Status, Trends and Challeges. Department of Higher Education Ministry of Higher Education 2011.

[9] García-Peñalvo, J., F., Conde, M. Á., Alier, M., \& Casany, M. J. (2011). Opening learning management systems to personal learning environments. Journal of Universal Computer Science, 17(9), 1222-1240.

[10] Ghaffar, M. N. A. (1999). Penyelidikan Pendidikan. Skudai: Penerbit Universiti Teknologi Malaysia.

[11] Hern'ndez, R., Amado-Salvatierra, H. R., Guetl, C., \& Smadi, M. (2012). Facebook for CSCL, Latin-American Experience for Professors. In 2012 IEEE 12th International Conference on Advanced Learning Technologies (pp. 327-328).

[12] Ishan Sudeera, A., \& Tham, C. Y. (2011). Implementation of Facebook Study Groups as Supplements for Learning Management Systems ( LMS ) in Adult ODL Environments. Asian Association of Open Universities Journal,, 7(1), 111.

[13] Li, C., Dong, Z., Untch, R., Chasteen, M., \& Reale, N. (2011). Peerspace-an online collaborative learning environment for computer science students. In 2011 11th IEEE International Conference on Advanced Learning Technologies (ICALT) (pp. 409-411).

[14] Marijana, D., Aleksandar, M., Zorica, B., Dušan, B., \& Krčo, S. (2012). Providing Adaptivity in Moodle LMS Courses Adaptive e-learning systems. Educational Technology \& Society, 15, 326-338.

[15] Marijana, D.-Z., Aleksandra, B. L., \& Aleksandar, R. M. (2011). Fostering engineering e-learning courses with social network services. In 19th IEEE Telecommunications Forum (TELFOR) (pp. 122-125).

[16] Mason, R. (2006). Learning technologies for adult continuing education. Studies in Continuing Education, 28(2), 121133.

[17] McCarthy, J. (2009). Utilising Facebook: immersing Generation-Y students into first year university. The Journal of the Education Research Group of Adelaide, 1(2), 39-50.

[18] Ractham, P., \& Firpo, D. (2011). Using Social Networking Technology to Enhance Learning in Higher Education: A Case Study Using Facebook. In 44th IEEE Hawaii International Conference on System Sciences (HICSS) (pp. 1-10). leee.

[19] Selwyn, N. (2007). "Screw Blackboard ... do it on Facebook!": an investigation of students ' educational use of Facebook. In Poke 1.0 - Facebook social research symposium' (pp. 1-23).

[20] Suthathip, M., \& Songrit, M. (2012). Can Facebook be a New Communicative Channel in a Student-Centered LMS? In The Asian Conference on Technology in the Classroom (pp. 115 - 129). 


\section{Author' biography with Photo}

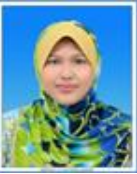

Sharifah Nadiyah Razali was a Senior Lecturer in Computer Systems and Support Program, Masjid Tanah Community College. Currently, she is working towards a PhD in IT degree at Universiti Teknikal Malaysia Melaka (UTeM). Her research interest are e-learning, Collaborative Learning and Networking System.

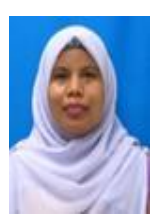

Faaizah Shahbodin is an Associate Professor at Faculty of Information and Communication Technology, Universiti Teknikal Malaysia Melaka (UTeM). She received her Degree in Computer Science in 1994 from Universiti Utara Malaysia (UUM), and Master in Computer Science in 1997 from Queensland University of Technology (QUT), Brisbane, Australia. She completed her Ph.D in Multimedia Education Systems at University Kebangsaan Malaysia (UKM).Her research interests are primarily on Problem Based Learning, multimedia applications, Creative Contents and User Interface Design. 